\title{
An Overview on the Public Relations Strategic Management in Public Sector Organizations
}

\author{
Darmawan Sidiq*, Rudy M. Harahap \\ Department of Accounting, Politeknik Keuangan Negara STAN, South Tangerang, Indonesia \\ *Corresponding author email: darmawan.sidiq@gmail.com
}

Received: 30 March 2019 / Revised: 20 May 2019 / Accepted: 29 May 2019 / Published: 01 June 2019

\begin{abstract}
Public relations are an important aspect that must be considered by public sector organizations to achieve its objectives. Strategic management is a valuable tool to aid public sector organizations in developing its public communication programs regarding the public relations. This paper attempts to explore the basic concepts that is important regarding the issue through literature review of several previous studies on public relations strategic management in public sector organizations. From these literature, this paper concludes that in order to achieve its public relations objectives, public sector organizations will have to: identify the groups that make up the public, understand the positioning of the organizations as well as the public groups; choose the best public relations strategy; and formulate the tailored messages to be communicated to each public groups according to the strategy chosen by the organization.
\end{abstract}

Keywords: public sector, strategic management, public relations

\section{Introduction}

Tazin and Yakoop (2015) explained that public is important for organization's achievement or disappointment. The notion is true regardless of the size and the nature of the business the organization deals with. Many issues arisen pertaining to the relations between organization and the public in the organization's day-to-day operations. Some of these issues are: working condition issues regarding safety and health; social justice issues regarding wages and workers' rights as well as human rights in general. Those issues encourage the development of public opinion as well as stakeholder activism. Freeman, 1984 (as cited by Hwabamungu, Brown, and Williams, 2018) defined stakeholders as any group or individual who can affect the achievement of the organisation's objectives as well as can be affected by the achievement of the organisation's objectives. Stakeholders themselves are already crucial when it comes to organization's achievement, especially when the stakeholders are engaging in activism.

Pertaining to public opinion development and stakeholder activism, pressure groups has been given the spotlight amidst the change in power dynamics. As the result of losing confidence in government, media and business, people embraced pressure groups. Pressure groups accumulate power of individuals so that their voices are more likely to be heard by those in power (Heath, 1997, as cited by Tazin and Yakoop, 2015). Organization have to address the change that had taken place. In order to ensure its stakeholder well-being as well as its good reputation remains unimpaired, organization must consider managing public policy as an important aspect to be taken care of. The public affected have to be consulted on regarding policies to be employed by organization. The communication is necessary in order to reach a common understanding. This step will prevent the failure of decision-making process (Tazin and Yakoop, 2015). The communication itself can be considered as a critical part of public participation. Public participation underlines the two-way communication rather than one-way communication. In the framework of public participation, problem solving must be achieved through collaboration rather than coercion. These 
An Overview on the Public Relations Strategic Management in Public Sector Organizations

principles will guide the problem-solving process to reach a solution that will be beneficial to all the parties that may be affected (International Association for Public Participation, as cited by Tazin and Yakoop, 2015). Public participation effectiveness tends to rely heavily on public relations (Tazin and Yakoop, 2015). The notion holds more truth especially in the public sector. The intimate relationship between public relations and democracy have been observed throughout the history of the United States, from the founding fathers of the United States to President Donald Trump. Democracy has always been influenced by the professional practice of public relations (Martinelli, 2011 as cited by LaMarre and Suzuki-Lambrecht, 2013). In order to improve its public relations, public sector organizations can utilize strategic management. Strategic management can help by becoming the basis during problems research; objective, public, and message planning; communication implementation. Those processes are performed within the constraint of certain timeframe, budget, and evaluation which will be more effective when strategic management is employed (Tazin and Yakoop, 2015). One of the public relation strategies that can be employed by organization is by breaking down the public into several categories. For each of the categories, organization identify their behavior on information. Behavioral aspects that need to be identified are: how they make use of information; how they pursue classifications of information; how they forecast information; and what are the impacts of information on them (Tazin and Yakoop, 2015).

This paper intends to perform a literature review to be able to explain the types of public relations strategies, public relations strategic planning, situational theory of publics, SWOT analysis as a tool in public relations strategy, and how the public relations strategic management is implemented in the public sector.

\section{Public Relations Strategies}

Several scholars had attempted to come up with the definition of public relations. One of the definitions is the definition proposed by Hazleton and Long (1988). According to Hazleton and Long (1988), as cited by Dodd and Collins (2017), public relations is an adaptive organizational process where communication is used to achieve goals. The communication strategies are therefore manifested into messages. These messages are intended to fulfill organization's objectives (Dodd and Collins, 2017). In order to enhance the effectiveness of the public relations, it is necessary to resort to some kind of strategies. Over the time, there have been numerous strategies employed by public relations practitioners. Those strategies have been studied and then codified by scholars to fit into seven categories, namely: informative; facilitative; persuasive; promise and reward; threat and punishment; bargaining; and cooperative problem solving (Hazleton and Long, 1988; Hazleton, 1993; Werder, 2006 as cited by Dodd and Collins, 2017).

\subsection{Informative Strategy}

Informative strategy can be viewed as the most simplistic form of public relations strategy. Facts are presented with biases prevented from taking place. Language used is those of utmost neutrality. This strategy encourages the public to shape their own thoughts and synthesize the conclusion of the messages themselves. It is limited in a way that it is rather naive and abstained from the effort of setting an agenda that will be necessary for the organization to influence the public to believe the ideas that the organization want the public to believe in (Hazleton and Long, 1988; Hazleton, 1993; Werder, 2006 as cited by Dodd and Collins, 2017).

\subsection{Facilitative Strategy}

Facilitative strategy shares some similarity with the informative strategy in a way that it does not try to plant an idea to the public. However, facilitative strategy does make use of the idea already residing in public. It brings in resources so that the idea the public already possess and already plan to carry out can be realized. Resources to bring in does not have to be money. It can be some other form of assets or benefits. From the ethics perspective, it will look like as bribery. In some cases, it may actually be a bribery (Hazleton and Long, 1988; Hazleton, 1993; Werder, 2006 as cited by Dodd and Collins, 2017). 


\subsection{Persuasive Strategy}

While facilitative strategy attempts to sway the public to perform the actions expected by the organization through the means of resources that may constitute economic benefits to be received by the affected public, persuasive strategy resorts to the way that can be viewed as appeal to the emotion. Humans are not a mere economic creature who are guided by the desire for wealth and constantly weighing profit and loss when considering their actions. At the same time, they are social creatures who internalized philosophies they are willing to uphold even though they may not obtain economic benefits in exchange for their actions. It is possible to exploit this trait using persuasive strategy. Among the means employed by persuasive strategy is the use of language that may include but not limited to call to action or any similar language that may provoke the public's heart (Hazleton and Long, 1988; Hazleton, 1993; Werder, 2006 as cited by Dodd and Collins, 2017).

\subsection{Promise and Reward Strategy}

Promise and reward strategy have a striking resemblance to the facilitative strategy. Both strategies aim to bring the public to the organization's side by bringing in resources up for grabs for the public. However, when it comes to promise and reward strategy, the bringing up of resources does not take place until the actions the organization intended to be taken by the public come into being. While a facilitative strategy will look like as bribery, when viewed from the perspective of ethics, a promise and reward strategy will look like as a gratification when all the conditions for the promise and reward strategy have been satisfied (Hazleton and Long, 1988; Hazleton, 1993; Werder, 2006 as cited by Dodd and Collins, 2017).

\subsection{Threat and Punishment Strategy}

As the name suggests, threat and punishment strategy is the antithesis of promise and reward strategy. Threat and punishment strategy dates back as early as several thousands of years ago. One way to illustrate the threat and punishment strategy is how wars have been fought throughout the history of humanity. A party may set some condition to be followed by the other parties like giving up on lands (annexation). Failure to comply with those conditions will result in the other parties to be attacked, their lands being taken by force, even their life may be taken as well whether through murder or slavery. The same principle still holds true in the modern days to the varying degree of brutality and ruthlessness (Hazleton and Long, 1988; Hazleton, 1993; Werder, 2006 as cited by Dodd and Collins, 2017).

\subsection{Bargaining Strategy}

While the previous four strategies do not require the existence of two-way communication, meaning that they could be achieved even if only one-way communication is employed, bargaining strategy, along with cooperative problem-solving strategy is not possible to execute unless two-way communication takes place. Bargaining strategy tries to address the interests of different groups by segregating the parties involved into several groups. As the consequences of that, those interests should be confronted to each other, bouncing back and forth, until a reconciliatory solution that will satisfy all parties achieved. Language that may characterize this category of public relations strategy is the words "we" or "they" (Hazleton and Long, 1988; Hazleton, 1993; Werder, 2006 as cited by Dodd and Collins, 2017).

\subsection{Cooperative Problem-solving Strategy}

As previously pointed out, cooperative problem-solving strategy is another strategy which require the twoway communication to be made available. Contrary to bargaining strategy, this category of public relations strategy uses the word "we", while minimizing the word "they" or "you (people)", carefully trying not to exclude the counterpart party, and end up treating them as an outsider subconsciously. Cooperative problem-solving strategy views the public as a dialogue partner and their willingness are important for the common interests shared between the organization and the public to come into fruition. It also resembles persuasive strategy a bit but with more emphasize on two-way communication and mutual understanding 
An Overview on the Public Relations Strategic Management in Public Sector Organizations

(Hazleton and Long, 1988; Hazleton, 1993; Werder, 2006 as cited by Dodd and Collins, 2017). Researchers have found the empirical evidences that Hazleton's (1993) categorization of public relations strategy is valid. Furthermore, as shown in research findings, it is known that the most popular strategies to be employed are the persuasive and informative strategies. Meanwhile, coercive and bargaining strategies are the rarer case in practice (Werder, 2006 as cited by Dodd and Collins, 2017). Thus, they can be considered as scientifically proven strategies to be employed in public relations strategic management pertaining to public sector organizations. However, the unique characteristics of public sector organizations might make its need of strategies to be different than those of private sector organizations. More caution should be taken, and additional considerations must be factored into in relation with the public sector organizations' public relations strategic management (Dodd and Collins, 2017).

\section{Public Relations Strategic Planning}

Tazin and Yakoop (2015) defined public relations strategic planning as a product of systematic research that aims to create a reliable communication programs for the public in any related issues that may arise. At any times, organization may face difficult situations that stem from public unrest. The public is comprised of several groups that have not-so-similar interest, size and structure. Those issues must be addressed in a manner that is the most beneficial to the organization. The opinion that is circulating in the public must not be left as it is as it may be running wild and goes beyond control. Organizations have to collect, monitor, and analyze these issues continuously in order to devise the most suitable response. Failure to do so might hamper organization's efforts in order to achieve its objectives. Public have common interests and collective views that necessary to be identified by organization -the result of the identification process also known as a problem statement- to gain a firm understanding on the situation currently affecting the public relevant to the organization in any given time.

\section{Situational Theory of Publics}

Upon the deliverance of a message, the reaction of an individual receiving the message will varies. The reaction will fall into one of these two categories: information seeking; and information processing. This taxonomy is devised through the means of the situational theory of publics (Aldoory, Kim, and Tindall, 2010). Situational theory of publics dictates that information seeking is more important. The reason for such notion is that in a public opinion discourses, active participants can be recognized by how they react when responding to those discourses. They are believed to manifest the information-seeking behavior when exposed to those discourses (Slater, Chipman, Auld, Keefe, and Kendall, 1992, p. 190, as cited by Aldoory, Kim, and Tindall, 2010). Scholars have defined information seeking as a type of behavior that show the action of purpose-oriented pursuit of information. From the definition, it can be inferred that the information pursuit cannot be meaningless. It must serve a purpose or philosophies of value that the individual believes in and therefore will react accordingly if the situations call for it (Aldoory, 2001; Grunig, 1997; Slater et al., 1992, as cited by Aldoory, Kim, and Tindall, 2010). Meanwhile, information processing can be defined with the same way with how information seeking is defined. However, it lacks the requirement of the active reaction that is required as per the information seeking definition. Additionally, the members of the public are not required to be actively pursuing information with regards to information processing behavior. The medium in which the messages are transmitted may varies, it can be audio / visual media such as television or radio, printed media such as pamphlet, and any other form of media (Aldoory, 2001; Grunig, 1989; Slater et al., 1992, as cited by Aldoory, Kim, and Tindall, 2010).

The increasingly overlapping of those two behaviors in the real-world situations that have taken place in recent times has led the researchers to develop a more innovative approach. Researchers combined the situational theory variables on the basis of the fact that the global environment has become more mediated (Kim and Grunig, 2007, as cited by Aldoory, Kim, and Tindall, 2010). Schillemans, 2012; Thorbjornsrud, Ustad Figenschou, \& Ihlen, 2014 (as cited by Fredriksson and Pallas, 2016) noted that the processes of mediatization has caused the increasing necessity of taking media into account in order to understand the 
Sidiq et al., Adv. J Social Sci.; Vol. 5 Issue 1, pp: 73-80, 2019

conditions of public sector organizations; how they work with public relations; and the reason to do so. The consequence is that those behaviors are no longer possible to be distinctly separated, they are becoming more fluid, and they may be exerted at the same time. Thus, a public information gaining is created due to these situations (Kim and Grunig, 2007, as cited by Aldoory, Kim, and Tindall, 2010).

In the situational theory of publics there are three variables that may affect the tendency towards certain situational theory of publics behavior. The probability can be whether an individual tends to display the information seeking or information processing behavior. Those variables are level of involvement, constraint recognition, and problem recognition which are independent of each other (Aldoory,2001; Grunig, 1997; Grunig and Hunt, 1984, as cited by Aldoory, Kim, and Tindall, 2010). Level of involvement refers to how much an issue is considered personally relatable by an individual. Any message pertaining to the issues which imply significant personal relatedness to an individual life will bear more impacts. Those impacts are: how the issue will be more possibly be reflected on; how the issue will be more easily noticeable; and how the issue will be processed with higher priority level (Aldoory, 2001; Grunig, 1997; Grunig and Hunt, 1984, as cited by Aldoory, Kim, and Tindall, 2010). Problem recognition can be explained as the degree of how people becoming aware of the problems pertaining to an issue. The awareness of the red flags that may affect the wellbeing of an individual or other party important to the individual comes with a consequence that when a problem is spotted, choice must be made. These choices then carried out into actions and the final phase is the putting of an end to the problems for good (Grunig, 1997, as cited by Aldoory, Kim, and Tindall, 2010).

Constraint recognition deals with the hindrances regarding the responses to be taken to deal with a problem. These hindrances may be not only actual hindrances but also perceived hindrances. When faced with a situation of limited information, individuals may perceive some hindrances in their mind that is actually completely imaginary. These hindrances will bring certain risks when attempting to carry out some selected responses (Aldoory, Kim, and Tindall, 2010). Researchers have found empirical evidences regarding the validity of the situational theory of publics. Aldoory and Van Dyke, 2004 (as cited by Aldoory, Kim, and Tindall, 2010) stated that a framework for studying responses to risk messages can be constructed using the situational theory of publics. Other researchers discovered that the formation of active public may be constructed through emotional arousal as shown in the study performed by Major, 1993 and Roser \& Thompson, 1995 (as cited by Aldoory, Kim, and Tindall, 2010). Public exerted information-seeking behavior when faced with problems and constraints no matter how their level of involvement scores (Major, 1993 as cited by Aldoory, Kim, and Tindall, 2010). Level of involvement can be generated by fear appeals as shown in the study by Roser \& Thompson, 1995 (as cited by Aldoory, Kim, and Tindall, 2010). These findings are consistent with the situational theory of publics as explained by Aldoory, Kim, and Tindall, 2010 as well as the public relation strategies taxonomy coined by Hazleton and Long, 1988; Hazleton, 1993; Werder, 2006 (as cited by Dodd and Collins, 2017). Shin (2008) study shows additional perspective. The study found that public relations professionals will exert certain actions with respect to the situations they are faced with. When dealing with conflict with a given public, they tend to exert collaborating, contending or compromising behaviors. Meanwhile, when faced with crisis, they are likely to use concession or corrective action to deal with the situation. However, the scope of the study is rather limited and must be taken with caution in a way that its scope is the religious public relations practitioners working for mainstream Protestant Christian churches in the United States.

\section{SWOT Analysis as a Tool in Public Relations Strategy}

In order to prepare messages for public, it is necessary for an organization to understand the positioning, both of itself and the public categories it strives to address. The positioning can be understood when an organization is able to identify the needs and wants of its audience. Once the positioning has been understood, organization will have to develop key message points. They are the statements that support and detailed the positioning that is being presented as the positioning of the organization. The key message points must be tailored to highlight certain issues that the organization wish to communicate to public 
An Overview on the Public Relations Strategic Management in Public Sector Organizations

(Kureczka, J. E., 2014). SWOT analysis will help a lot when it comes to determine the positioning. SWOT analysis have been a big help in many sectors such as business, education, healthcare, and urban and land use planning (Paschalidou et al., 2016; Zharan and Bongaerts, 2017, Hlungwani, 2017, Aslan et al., 2014, Kazemi et al., 2018, as cited by Cui, Allan, Lin, 2019). However, there is some criticisms for SWOT analysis. It is traditionally a form of brainstorming that is likely to contain subjective views of the participating individuals. Furthermore, SWOT factors are considered not prioritized by their significance. As the result, its effectiveness to provide the proper strategic action has been questioned by some researchers as well (Phadermrod, Crowder, and Wills, 2016).

SWOT analysis consists of strengths (S), weaknesses (W), opportunities $(\mathrm{O})$, and threats $(\mathrm{T})$ analysis. This type of analysis will aid the organization to obtain a helicopter view that is comprised of the aspects of importance to the business conducted by the organization as well as the environment that becoming the medium in which the organization's actions materialized. In the framework of SWOT analysis, internal natures of the organization are amounted as its strengths and weaknesses. Meanwhile, the natures of the environment, which is the business landscape the organization operates in, are amounted as the organization's opportunities and threats. These external factor's effect on the organization successfulness, along with the internal factors, must be understood to gain the most comprehensive knowledge on how to construct the best possible messages to address each of the situations to occur (Kureczka, J. E., 2014).

The elaboration of messages will be immensely helped if a SWOT analysis is performed well enough. SWOT analysis will enable organization to highlight its unique value propositions relative to other organizations in the same field. The effort to recognize the differentiating factors that the organization possess does not take a blink of an eye. Significant amount of time is expected to be invested to the effort. Among the uniquenesses that the organization should strive to extract are its important business and scientific characteristics, market opportunities, and the products to be delivered to its stakeholders (Kureczka, J. E., 2014). When the uniquenesses have successfully been identified, the next step required is to devise the way in which the messages about the uniqueness can be conveyed to stakeholders. An effective way is the way which is clear, concise, but not attracting too many unsolicited attentions (hype). In the long run, the effective formulation process regarding the positioning and messages can be harvested as strong brand value and consistent communications (Kureczka, J. E., 2014).

\section{Putting Public Relations Strategic Management into Practice}

The study conducted by Tazin and Yakoop (2015) provides empirical evidence on how a public sector organization can benefits from the implementation of public relations strategic management. The object being studied is the Majlis Perbandaran Ampang Jaya (Municipal Council of Ampang Jaya). It is an authority agency of a local level which is responsible for the execution of town and country planning in slope development area. The jurisdiction it has authority on is the town of Ampang Jaya, State of Selangor, Malaysia, sometimes simply referred as Ampang. Ampang is a town adjacent to Kuala Lumpur, Malaysia. Policies and regulations in developing slope area in the state of Selangor have been considered seriously by the Malaysian authorities following the aftermath of Highland Towers tragedy in Taman Hillview, Hulu Kelang, Selangor, Malaysia. It was in 2002 that the disaster of landslide took place. It had claimed sizable fatalities in the process. As the result, various groups of public have called on the state government and local agencies to improve the maintenance and regulation of the slope area, especially in Ampang, a posh neighborhood of Selangor (Tazin and Yakoop, 2015).

According to the Local Plans (Act 172), it is of utmost importance to obtain feedbacks from public participation, before any change to Local Plans awarded an approval. As the department responsible for the development of slope area classified as class III (slopes in the interval between 26 and 35 degrees) and class IV (slopes greater than 35 degrees), the tasks of managing public participation regarding slope development becomes the role of the Department of Urban Planning and Slope Unit, an engineering department of Majlis Perbandaran Ampang Jaya. With regards to public relations strategic management, it 
Sidiq et al., Adv. J Social Sci.; Vol. 5 Issue 1, pp: 73-80, 2019

is of paramount significance for the Majlis Perbandaran Ampang Jaya to have a strategic planning for its public participation program (Tazin and Yakoop, 2015).

The study has explained the core problems faced by Majlis Perbandaran Ampang Jaya pertaining to this situation. Issues that is affected are: planning; construction; maintenance; enforcement; legislation; hillside failure; and landslides. Other than problem identification, the study also successfully explained the public groups segregation determined by Majlis Perbandaran Ampang Jaya to be considered when formulating public communication programs going forward. These groups are: "the salient group" which has been actively questioning Majlis Perbandaran Ampang Jaya credibility in developing slope area; and "the silent group" which have been observing situations on slope development but chose to not voice their concerns (Tazin and Yakoop, 2015).

In order to improve awareness on slope development more effectively, it is necessary to not engage all public groups in a one-size-fits-all program. Therefore, Majlis Perbandaran Ampang Jaya segregated the public groups and tailor the program to match with each of the public groups. As a result, public who understood the messages supported Majlis Perbandaran Ampang Jaya in developing slope area so that the landslides can be prevented from occurring again. In addition, the two-way communication had been incorporated into public communication programs in order to achieve favorable behavioural change towards Majlis Perbandaran Ampang Jaya, improve mutual understanding, and make transparent decisionmaking process becomes possible (Tazin and Yakoop, 2015). The various strategic public involved in the slope development issue is dynamic. They can change from being apathetic to being hot-issue public. These changes depend on the level of involvement of those groups to the issues in question. The purpose of the messages to public is to describe how committed Majlis Perbandaran Ampang Jaya towards the development of a sustainable environment to the betterment of the living of the society (Tazin and Yakoop, 2015).

\section{Conclusion}

Public relations are already a complicated process, especially for the public sector organizations. Therefore, it is beneficial for the public sector organizations to seek the help of strategic management in order to leverage the public relations effectiveness. Public sector organizations will have to: identify the groups that make up the public, understand the positioning of the organizations as well as the public groups; choose the best public relations strategy; and formulate the tailored messages to be communicated to each public group according to the strategy chosen by the organization.

\section{Competing Interests}

The authors declared that they do not have any potential conflict of interest in publishing this article.

\section{How to Cite this Article:}

Sidiq, D., \& Harahap, R. (2019). An Overview on the Public Relations Strategic Management in Public Sector Organizations. Advanced Journal of Social Science, 5(1), 73-80. doi:10.21467/ajss.5.1.73-80

\section{References}

Aldoory, L. (2001). Making health communications meaningful for women: Factors that influence involvement. Journal of Public Relations Research, 13, 163-185.

Aldoory, L., \& Van Dyke, M. (2004, August). Shared involvement and risk perception in responding to bioterrorism: An extension of the situational theory of publics. In Paper presented to the association for education in journalism and mass communication Toronto, Canada.

Aldoory, L., Kim, J.-N., \& Tindall, N. (2010). The influence of perceived shared risk in crisis communication: Elaborating the situational theory of publics. Public Relations Review, 36(2), 134-140.

Aslan, I., Çınar, O., Özen, Ü., 2014. Developing strategies for the future of healthcare in Turkey by benchmarking and SWOT analysis. Proc.Soc. Behav. Sci. 150, 230-240.

Cui, J., Allan, A., \& Lin, D. (2019). SWOT analysis and development strategies for underground pedestrian systems. Tunnelling and Underground Space Technology, 87, 127-133.

Dodd, M. D., \& Collins, S. J. (2017). Public relations message strategies and public diplomacy 2.0: An empirical analysis using CentralEastern European and Western Embassy Twitter accounts. Public Relations Review, 43(2), 417-425. 
Fredriksson, M., \& Pallas, J. (2016). Much ado about media: Public relations in public agencies in the wake of managerialism. Public Relations Review, 42(4), 600-606.

Freeman, R. E. (1984). Strategic management: a stakeholder approach. Boston: Pitman.

Grunig, J. E., \& Hunt, T. (1984). Managing public relations. New York: Holt, Rinehart and Winston.

Grunig, J. E. (1989). Sierra Club study shows who becomes activists. Public Relations Review, 15(3), 3-24.

Grunig, J. E. (1997). A situational theory of publics: Conceptual history, recent challenges, and new research. In D. Moss, T. MacManus, \& D. Vercic (Eds.), Public relations research: An international perspective (pp. 3-48). London: International Thomson Business Press.

Hazleton, V., \& Long, L.W. (1988). Concepts for public relations education, research, and practice: A communication point of view. Central States Speech Journal, 39, 77-87.

Hazleton, V. (1993). Symbolic resources: Processes in the development and use of symbolic resources. In W. Armbrecht, H. Avenarius, \& U. Zabel (Eds.), Image and PR: Can image be a subject of public relations science? (pp. 87-100). Westdeutscher Verlag; Wiesbaden, Germany

Heath, R. L. (1997). Strategic issues management: Organizations and public policy challenges. Thousand Oaks: Sage publications

Hlungwani, S., 2017. Analysis of the current situation of nursing education in South Africa (SWOT). Int. J. Nurs. Sci. 4 (4), 348.

Hwabamungu, B., Brown, I., \& Williams, Q. (2018). Stakeholder influence in public sector information systems strategy implementationThe case of public hospitals in South Africa. International Journal of Medical Informatics, 109, 39-48.

International Association of Public Participation. (2017). IAP2 Core Values. Retrieved March 30, 2019, from https://www.iap2.org/page/corevalues

Kazemi, F., Abolhassani, L., Rahmati, E.A., Sayyad-Amin, P., 2018. Strategic planning for cultivation of fruit trees and shrubs in urban landscapes using the SWOT method: a case study for the city of Mashhad, Iran. Land Use Policy 70, 1-9.

Kim, J.-N., \& Grunig, J. (2007, May). Explicating and validating communicant activeness in problem solving (CAPS). In Paper presented to international communication association San Francisco, CA.

Kureczka, J. E. (2014). Getting the Word Out. Biotechnology Entrepreneurship, 257-265.

LaMarre, H. L., \& Suzuki-Lambrecht, Y. (2013). Tweeting democracy? Examining Twitter as an online public relations strategy for congressional campaigns. Public Relations Review, 39(4), 360-368.

Major, A. M. (1993). Environmental concern and situational communication theory: Implications for communicating with environmental publics. Journal of Public Relations Research, 5, 251-268.

Martinelli, D. K. (2010, July). A practical and theoretical look at women's use of public relations to spur early- to mid-20th century U.S. social change. In Paper Presented at the First International Public Relations History Conference Bournemouth, England.

Paschalidou, A., Tsatiris, M., Kitikidou, K., 2016. Energy crops for biofuel production or for food? - SWOT analysis (case study: Greece). Renew. Energy 93, 636-647.

Phadermrod, B., Crowder, R. M., \& Wills, G. B. (2016). Importance-Performance Analysis based SWOT analysis. International Journal of Information Management.

Roser, C., \& Thompson, M. (1995). Fear appeals and the formation of active publics. Journal of Communication, 45, $103-119$.

Schillemans, T. (2012). Mediatization of Public Services. How organizations adapt to news media. Frankfurt: Peter Lang.

Shin, J.-H. (2008). Contingency, conflict, crisis: Strategy selection of religious public relations professionals. Public Relations Review, 34(4), $403-405$.

Slater, M. D., Chipman, H., Auld, G., Keefe, T., \& Kendall, P. (1992). Information processing and situational theory: A cognitive response analysis. Journal of Public Relations Research, 4, 189-203.

Tazin, S. N. M., \& Yaakop, S. H. (2015). Strategic Management of Public Relations in Slope Development: Case Study in Malaysia. Procedia - Social and Behavioral Sciences, 168, 302-310.

Thorbjornsrud, K., Ustad Figenschou, T., \& Ihlen, Ø. (2014). Mediatization in public bureaucracies: a typology. Communications-The European Journal of Communication Research, 39(1), 3-22.

Werder, K. P. (2006). Responding to activism: An experimental analysis of public relations strategy influence on attributes of publics. Journal of Public Relations Research, 18(4), 335-356.

Zharan, K., Bongaerts, J.C., 2017. Decision-making on the integration of renewable energy in the mining industry: a case studies analysis, a cost analysis and a SWOT analysis. J. Sustainable Min. 16 (4), 162-170.

Publish your research article in AIJR journals-

$\checkmark \quad$ Online Submission and Tracking

$\checkmark$ Peer-Reviewed

$\checkmark \quad$ Rapid decision

$\checkmark \quad$ Immediate Publication after acceptance

$\checkmark \quad$ Articles freely available online

$\checkmark \quad$ Retain full copyright of your article.

Submit your article at journals.aijr.in
Publish your books with AIJR publisher-

$\checkmark$ Publish with ISBN and DOI.

$\checkmark$ Publish Thesis/Dissertation as Monograph.

$\checkmark$ Publish Book Monograph.

$\checkmark$ Publish Edited Volume/ Book.

$\checkmark$ Publish Conference Proceedings

Retain full copyright of your books.

Submit your manuscript at books.aijr.org 